\title{
Penggunaan Analytical Hierarchy Process dalam Penentuan Prioritas Penyuluhan Perikanan di Wilayah Perkotaan pada Pengelolaan Usaha Budidaya Perikanan: Kasus di Kota Bogor
}

\author{
[Priority Analysis Fisheries Extension at the Business Management \\ Aquaculture in Urban Areas: Case in Bogor City] \\ Fahrur Razi \\ Pusat Penyuluhan dan Pemberdayaan Masyarakat Kelautan dan Perikanan \\ Jalan Medan Merdeka Timur No 16 Gedung. Mina Bahari III lantai 5 Jakarta Pusat 10110
}

Diterima: 08 Januari 2016; disetujui: 26 April 2016

\begin{abstract}
Abstrak
Kegiatan penyuluhan budidaya ikan merupakan salah satu faktor yang dianggap penting untuk diterapkan dengan baik di Bogor sebagai salah satu wilayah perkotaan di negara ini. Tujuan dari penelitian ini adalah: (1) menentukan materi/informasi penyuluhan perikanan yang akan disampaikan untuk mengatasi permasalahan-permasalahan dan aspek-aspek terkini dalam usaha budidaya perikanan di wilayah perkotaan; (2) menentukan prioritas terhadap materi/ informasi penyuluhan perikanan; (3) menentukan pilihan alternatif sebagai strategi penyuluhan perikanan yang efektif pada pengelolaan usaha budidaya ikan di wilayah perkotaan. Penelitian ini merupakan penelitian kualitatif dengan menggunakan desain eksplorasi yang diarahkan untuk memprioritaskan isu-isu tersebut dengan menerapkan Analytical Hierarchy Process (AHP). Sampel penelitian merupakan panel pakar/ahli yang terdiri dari sembilan responden (mewakili pembudidaya ikan, pejabat pembina, pengambil keputusan, dan akademisi) dibentuk untuk mengembangkan prioritas masalah penyuluhan budidaya perikanan secara sistematis dengan menggunakan AHP. Ada delapan isu utama yang digunakan dalam penelitian ini, dimana setiap isu terdiri dari tiga sampai lima sub isu. Metode analisis data pada penelitian ini terdiri dari: (a) penilaian/pembandingan elemen berpasangan; (b) penyusunan matriks eigenvector berpasangan ternormalisasi dan uji konsistensi; dan (c) penetapan prioritas pada masing-masing hirarki. Penelitian ini menemukan bahwa penerapan budidaya yang ramah lingkungan dan pelestarian ekosistem berada dalam prioritas utama dari kriteria materi/informasi penyuluhan di kota Bogor. Pengembangan usaha budidaya ikan yang produktif dan berkelanjutan adalah prioritas lain yang dianggap sebagai sub-kriteria utama dari materi/informasi penyuluhan budidaya perikanan. Selain itu, juga ditemukan bahwa kegiatan penyuluhan budidaya perikanan berbasis keterampilan adalah strategi yang paling efektif di daerah perkotaan seperti Kota Bogor.
\end{abstract}

Kata kunci: Analytical Hierarchy Process (AHP), pengelolaan usaha perikanan, penyuluhan perikanan, wilayah perkotaan

\begin{abstract}
Abstrack
As an independent town, the city of Bogor is in the process of developing to provide better living environment to its inhabitants. Aquaculture extension activities is one of the factors that are considered to be important to be applied properly in Bogor as one of the urban region in the country. A problems are faced in implementing aquaculture extension activities in the city of Bogor: current aquaculture issues are not integrated properly into the extension program planning; extension materials are not designed well to indicate prioritization of the issues; and no adequate tools to prioritize the important aquaculture extension issues appropriately. This study is a qualitative research design using exploration directed to prioritize these issues by applying Analytical Hierarchy Process. An Expert Panel of nine resource persons was set up to develop the priritization of

$\bar{\triangle}$ Penulis korespondensi

Alamat surel: fahrul.perikanan@gmail.com
\end{abstract}


aquaculture extension issues systematically by employing AHP. There are 8 main issues in this research, each issues consists of 3-5 sub issues. Methods of data analysis in this study consists of: (a) evaluation/comparison element pairs; (b) preparation of pairs of normalized eigenvector matrix and consistency test; (c) prioritization at the each hierarchy. The study found that environment-friendly aquaculture practices and ecosystem sustainability are in the top priorities of the extension issues in Bogor city. Productive and sustainable aquaculture businesses are the other priorities considered as main sub-issues of aquaculture extension information. In addition, it is also found that skill-based aquaculture extension activities are the most effective strategy in urban areas like Bogor city.

Keywords: management of fishery business, fisheries extension, urban area, Analytical Hierarchy Process (AHP)

\section{PENDAHULUAN}

Kota Bogor terletak $59 \mathrm{~km}$ sebelah selatan Jakarta, kedudukan topografis Kota Bogor ditengah-tengah wilayah Kabupaten Bogor serta lokasinya yang dekat dengan Ibu Kota Negara, merupakan potensi yang strategis untuk perkembangan dan pertumbuhan ekonomi. Menurut data Badan Pusat Statistik Provinsi Jawa Barat (2015), pada tahun 2014 di Kota Bogor terdapat $34 \mathrm{Ha}$ areal pemeliharaan ikan, 830 Rumah Tangga Perikanan (RTP) Budidaya, dan 36 unit pengolahan hasil perikanan.

Sumber daya alam itu belum dapat dikelola secara maksimal, oleh karenanya diperlukan sumber daya manusia yang handal dan professional, yang dapat mengelola potensi sumber daya alam perikanan secara cerdas dan bertanggung jawab. Kegiatan penyuluhan perikanan diharapkan mendorong terwujudnya masyarakat perikanan menuju kehidupan lebih layak, berusaha yang lebih menguntungkan, dan kehidupan yang lebih sejahtera (Hanan dkk, 2013)

Sumberdaya alam dan sumberdaya manusia yang dimiliki oleh Kota Bogor dapat dijadikan sebagai modal awal pada pengembangan suatu ekonomi berbasis perikanan dalam rangka guna masyarakat yang sejahtera. Kota ditinjau dari aspek demografis merupakan wilayah dengan konsentrasi penduduk, baik jumlah dan tingkat kepadatan yang lebih tinggi dibandingkan wilayah sekitarnya. Secara umum kegiatan produksi untuk barangbarang primer, sekunder, dan tersier, maupun juga produksi jasa, lebih memungkinkan dilakukan di wilayah perkotaan daripada di wilayah pedesaan. Penyuluhan perikanan memiliki peran strategis sebagai sistem pendidikan non formal dalam transformasi masyarakat perikanan pada pengembangan usaha yang lebih baik. Permasalahan yang mendasari penelitian ini adalah: (1) permasalahanpermasalahan dan aspek-aspek terkini sedang dihadapi oleh pembudidaya ikan 
dalam usahanya di wilayah perkotaan, belum ditetapkan sebagai materi/informasi yang juga akan disampaika melalui penyuluhan perikanan. (2) belum ada prioritas terhadap materi atau informasi penyuluhan perikanan sesuai kebutuhan; dan (3) belum adanya sistem pendukung keputusan untuk penentuan prioritas dari alternatif strategi penyuluhan perikanan.

Tujuan dari penelitian ini adalah: (1) Menganalisis materi/informasi penyuluhan perikanan yang akan disampaikan untuk mengatasi permasalahan-permasalahan dan aspek-aspek terkini yang dihadapi oleh pembudidaya ikan dalam usahanya di wilayah perkotaan; (2) Menganalisis prioritas terhadap materi/informasi penyuluhan perikanan yang dibutuhkan oleh pembudidaya ikan di area wilayah perkotaan untuk mengatasi permasalahanpermasalahan yang dihadapi dalam usahanya; dan (3) Menganalisis pilihan alternatif sebagai strategi penyuluhan perikanan yang efektif dan tepat di wilayah perkotaan pada pengelolaan usaha budidaya ikan yang sesuai kebutuhan pembudidaya ikan atau kelompok sebagai sasaran penyuluhan.

Amanah dkk (2004) yang melakukan suatu penelitian pemodelan penyuluhan perikanan dan merumuskan dua model alternatif yang relevan: (a) pendekatan penyuluhan yang mampu meningkatkan kapasitas masyarakat dalam melakukan perencanaan, stimulasi pembangunan wilayah lokal, dan penguatan sosial ekonomi masyarakat; dan (b) model memotivasi masyarakat, yang intinya adanya kemauan masyarakat dalam mendayagunakan sumber daya ikan tanpa menyebabkan kerusakan lingkungan.

Sementara itu, penelitian tentang sistem penyuluhan perikanan dalam mengantisipasi era perubahan, yang juga telah dilakukan oleh Amanah (2008), menyimpulkan perubahan yang dihadapi dan harus diantisipasi melalui sistem penyuluhan perikanan, meliputi: (a) perubahan kondisi sumber daya alam, (b) perubahan kebijakan dan atau strategi pembangunan perikanan, (c) prioritas tuntutan kebutuhan masyarakat, dan (d) perubahan teknologi dan modernisasi.

Terkait dengan pembudidaya ikan, Fatchiya (2010) menyarankan agar strategi pengembangan kapasitas pembudidaya ikan ditentukan oleh iklim usaha yang kondusif. Iklim tersebut dibangun oleh kelembagaan agribisnis yang mendorong pengembangan usaha, kinerja penyuluh perikanan yang tinggi, pada kelompok perikanan yang dinamis, dengan materi pembelajaran sesuai dengan masalah yang dihadapi oleh pembudidaya ikan setempat.

Dalam pada itu, Salampessy (2012) mengungkapkan bahwa penentuan suatu 
informasi/materi penyuluhan yang akan diberikan kepada kelompok masyarakat sebagai sasaran penyuluhan, harus bersifat buttom up (bersumber dari masyarakat) karena penyuluh hanya berstatus sebagai fasilitator. Hal ini terkait dengan hasil penelitian Rijayana dan Okirindho (2012) yang mengungkapkan bahwa kemampuan mengambil keputusan yang cepat dan cermat akan menjadi kunci keberhasilan dalam persaingan global dan untuk mengambil sebuah keputusan tentu saja diperlukan berbagai analisis-analisis dan perhitungan cukup matang, tergantung dengan banyak sedikitnya kriteria yang dapat mempengaruhi permasalahan yang membutuhkan suatu keputusan yang tepat. Pengambilan suatu keputusan dengan banyak kriteria memerlukan suatu cara penanganan khusus terutama bila kriteria pengambilan keputusan tersebut saling terkait, untuk itu dibutuhkan suatu model sebelum satu keputusan diambil. Pada pemilihan para staf/karyawan berprestasi berdasarkan pada kinerja di Universitas Widyatama, AHP dapat juga dimanfaatkan sebagai proses pengambilan keputusan yang sangat baik di bidang sumberdaya manusia secara logis dan konsisten.

Rochmasari dkk (2010), merincikan langkah-langkah dalam metode AHP meliputi: (a) menyusun suatu hirarki dari permasalahan yang dihadapi; (b) penilaian kriteria dan alternatif; (c) penentuan prioritas; (d) konsistensi logis; dan (e) sintesis hasil penelitian.

Beberapa hal dan kondisi yang dapat disimpulkan dari penelitian terdahulu: (1) pendekatan penyuluhan harus mampu memotivasi peran aktif masyarakat perikanan dalam tahapan peningkatan kapasitasnya, (2) sistem penyuluhan perikanan harus dapat mengantisipasi era perubahan sumberdaya serta tuntutan kebutuhan masyarakat perikanan, (3) strategi terhadap pengembangan kapasitas pembudidaya ikan harus mendukung iklim usaha yang kondusif, melalui materi pembelajaran sesuai dengan masalah yang dihadapi dan dengan kesesuaian terhadap sumberdaya yang dimiliki, (4) penentuan informasi/materi penyuluhan harus bersifat buttom up (bersumber dari masyarakat sasaran), dan (5) AHP dapat dimanfaatkan sebagai sistem pendukung keputusan yang sangat baik di bidang sumberdaya manusia secara logis dan konsisten. Penelitian ini akan membuat sebuah sistem pendukung keputusan dalam penentuan prioritas dari alternatif-alternatif strategi penyuluhan, dengan mengklasifikasikan kebutuhan pembudidaya ikan terhadap materi dan atau informasi penyuluhan perikanan di wilayah perkotaan berdasarkan kriteria yang banyak. 


\section{BAHAN DAN METODE}

Penelitian ini merupakan penelitian kualitatif dengan menggunakan desain eksploratori dalam penentuan prioritas penyuluhan kegiatan perikanan di wilayah perkotaan pada suatu pengelolaan usaha budidaya ikan dengan tetap menggunakan metode Analytical Hierarchy Process (AHP). Hirarki AHP disusun sebagai kerangka pengambilan keputusan yang efektif efisien dengan menyederhanakan pemecahan persoalan melalui variabelvariabel dalam suatu susunan hirarki. Dengan hirarki, suatu masalah yang kompleks dapat diuraikan ke dalam kelompok-kelompoknya yang kemudian diatur menjadi suatu bentuk hirarki sehingga permasalahan akan tampak lebih terstruktur dan sistematis. Hirarki AHP yang disusun pada penelitian ini terdiri empat level, dimana level pertama adalah tujuan, yang diikuti level kedua berupa kriteria, level ketiga berupa sub kriteria, dan level keempat berupa alternatif.

Sampel penelitian ini berjumlah sembilan orang ahli/pakar, terdiri dari unsur: pembudidaya ikan, penyuluh perikanan, instansi pembina, pemerintah daerah, dan akademisi. Instrumen yang digunakan adalah kuisioner yang didesain berdasarkan kepada metode AHP untuk mendapatkan kriteria, sub kriteria, dan alternatif yang didasarkan pada tingkat kepentingan dan kisaran skala 1 sampai 9 terhadap satu sama lain. Pengumpulan data dilakukan dengan metode: studi literatur, studi di lapangan, pengisian kuesioner, wawancara, termasuk observasi lapangan. Hirarki AHP pada penelitian ini dapat dilihat/simak pada Gambar 1 berikut ini.

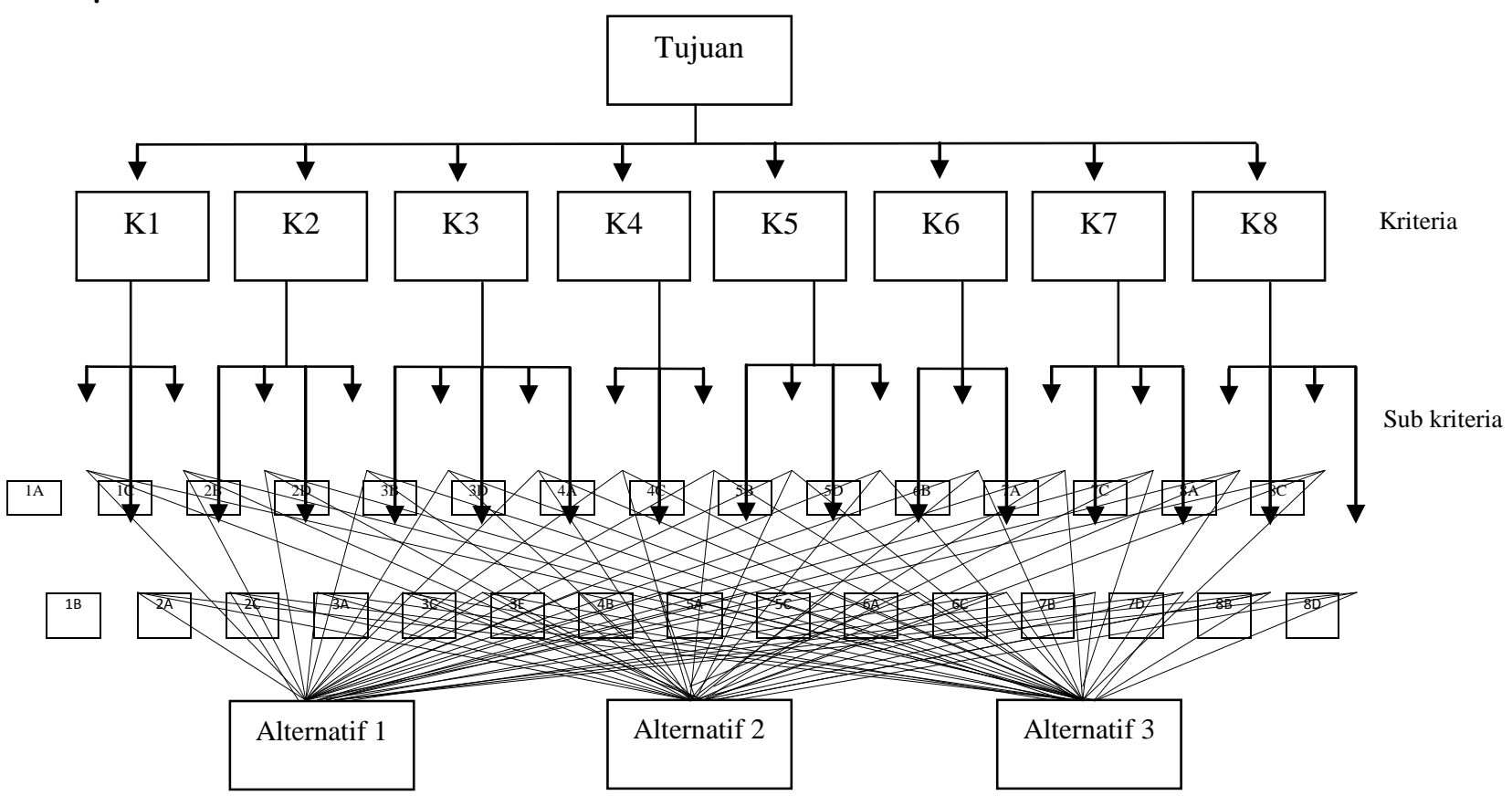

Gambar 1. Hirarki AHP pada Penelitian 
Penggunaan Analytical Hierarchy Process dalam Penentuan Prioritas Penyuluhan Perikanan di Wilayah Perkotaan pada Pengelolaan Usaha Budidaya Perikanan: Kasus di Kota Bogor

Keterangan Gambar 1.

\begin{tabular}{|c|c|}
\hline Tujuan & Uraian \\
\hline Tujuan & $\begin{array}{l}\text { Menentukan prioritas penyuluhan perikanan yang efektif di wilayah } \\
\text { perkotaan pada pengelolaan usaha budidaya ikan sesuai kebutuhan } \\
\text { pembudidaya ikan sebagai sasaran penyuluhan }\end{array}$ \\
\hline Kriteria & Uraian \\
\hline $\mathrm{K} 1$ & $\begin{array}{l}\text { Penumbuhan dan pengembangan peran dan fungsi kelompok } \\
\text { perikanan }\end{array}$ \\
\hline $\mathrm{K} 2$ & Penyusunan aturan pengelolaan keuangan usaha perikanan \\
\hline K3 & Penguasaan teknis budidaya perikanan \\
\hline K4 & Pembangunan kemitraan strategis \\
\hline K5 & Pembangunan jejaring pemasaran \\
\hline K6 & Penyusunan perencanaan dan pengembangan usaha \\
\hline K7 & Penyusunan SOP budidaya perikanan \\
\hline K8 & $\begin{array}{l}\text { Penerapan budidaya perikanan yang ramah lingkungan dan } \\
\text { pelestarian ekosistem }\end{array}$ \\
\hline Sub kriteria & Uraian \\
\hline $1 \mathrm{~A}$ & Penumbuhan kelompok \\
\hline 1B & Peran dan fungsi kelompok \\
\hline $1 \mathrm{C}$ & Pengelolaan manajerial kelompok \\
\hline $2 \mathrm{~A}$ & Perencanaan keuangan \\
\hline 2B & Pencatatan dan pemeriksaan keuangan \\
\hline $2 \mathrm{C}$ & Analisis pengelolaan keuangan \\
\hline $2 \mathrm{D}$ & Kesehatan keuangan \\
\hline $3 \mathrm{~A}$ & Pengelolaan wadah budidaya \\
\hline $3 \mathrm{~B}$ & Pengelolaan benih dan induk \\
\hline $3 \mathrm{C}$ & Pengelolaan pakan \\
\hline $3 \mathrm{D}$ & Pengelolaan kualitas air \\
\hline $3 \mathrm{E}$ & Pengelolaan hama dan penyakit ikan \\
\hline $4 \mathrm{~A}$ & Kemitraan dalam peningkatan keuntungan \\
\hline 4B & Kemitraan dengan pemasok bahan baku atau sarana produksi \\
\hline $4 \mathrm{C}$ & Kemitraan dengan lembaga keuangan/perbankan \\
\hline $5 \mathrm{~A}$ & Menghasilkan produk sesuai kebutuhan pasar \\
\hline $5 \mathrm{~B}$ & Membangun jaringan pemasaran tingkat lokal (kabupaten/kota) \\
\hline $5 \mathrm{C}$ & Membangun jaringan pemasaran tingkat provinsi/nasional \\
\hline $5 \mathrm{D}$ & Membangun jaringan pemasaran internasional \\
\hline $6 \mathrm{~A}$ & Perencanaan teknis, keuangan dan produksi \\
\hline $6 \mathrm{~B}$ & Perencanaan usaha yang realistis \\
\hline $6 \mathrm{C}$ & Pengembangan usaha yang produktif dan berkelanjutan \\
\hline $7 \mathrm{~A}$ & Penyusunan tahapan dan skema produksi \\
\hline $7 \mathrm{~B}$ & Penyusunan pola tanam dan jadwal produksi \\
\hline $7 \mathrm{C}$ & Pelaksanaan sanitasi dan higienis \\
\hline 7D & Pencatatan dan penyusunan laporan \\
\hline $8 \mathrm{~A}$ & Kegiatan budidaya ikan yang ramah lingkungan \\
\hline $8 \mathrm{~B}$ & Penggunaan sumber daya yang efisien \\
\hline $8 \mathrm{C}$ & Manfaat ekonomi bagi masyarakat \\
\hline $8 \mathrm{D}$ & Manfaat sosial bagi masyarakat \\
\hline Alternatif & Uraian \\
\hline Alternatif 1 & Pengetahuan \\
\hline Alternatif 2 & Keterampilan \\
\hline Alternatif 3 & Sikap \\
\hline
\end{tabular}


Metode analisis data pada penelitian ini terdiri dari: (a) penilaian atau suatu pembandingan elemen berpasangan, (b) penyusunan matriks eigen vector yang dilakukan berpasangan ternormalisasi dengan uji konsistensi, dan (c) penetapan dan pengisian kuisioner oleh para pakar atau para ahli yang dijadikan responden. Pengolahan data kegiatan perbandingan berpasangan yang dilakukan menggunakan aplikasi BPMSG AHP excel template with multiple inputs version 07.06.2015 yang dibuat oleh K. D. Goepel dan didownload prioritas pada perlakuan masing-masinghirarki.

\section{HASIL DAN PEMBAHASAN}

Temuan hasil penelitian diperoleh dengan mengolah data hasil wawancara dan diakses http://bpmsg.com/10/2/2015. Data atau informasi hasil pengolahan data melalui Aplikasi BPMSG AHP excel template with multiple inputs version 07.06.2015 yang telah dijalankan dengan menggunakan program MS Excel 2010

Tabel 1. Nilai Relatif Berpasangan antara Kriteria Materi/Informasi Penyuluhan Perikanan yang diprioritaskan di Wilayah Perkotaan pada Pengelolaan Usaha Budidaya Ikan

\begin{tabular}{ccccccccc}
\hline & $\mathrm{a}$ & $\mathrm{b}$ & $\mathrm{c}$ & $\mathrm{d}$ & $\mathrm{e}$ & $\mathrm{f}$ & $\mathrm{g}$ & $\mathrm{h}$ \\
\hline $\mathrm{a}$ & 1 & 2,395 & 0,693 & 1,187 & 0,68 & 0,685 & 0,926 & 0,487 \\
$\mathrm{~b}$ & 0,418 & 1 & 0,693 & 0,794 & 0,426 & 0,475 & 0,68 & 0,329 \\
$\mathrm{c}$ & 1,442 & 1,442 & 1 & 1,898 & 1,379 & 1,046 & 1,204 & 0,783 \\
$\mathrm{~d}$ & 0,843 & 1,26 & 0,527 & 1 & 0,735 & 0,956 & 0,885 & 0,685 \\
$\mathrm{e}$ & 1,47 & 2,347 & 0,725 & 1,361 & 1 & 0,685 & 0,774 & 0,537 \\
$\mathrm{f}$ & 1,459 & 2,105 & 0,956 & 1,046 & 1,459 & 1 & 1,379 & 0,903 \\
$\mathrm{~g}$ & 1,08 & 1,47 & 0,83 & 1,13 & 1,292 & 0,725 & 1 & 0,784 \\
$\mathrm{~h}$ & 2,053 & 3,035 & 1,277 & 1,459 & 1,863 & 1,107 & 1,275 & 1 \\
\hline$\sum$ & $\mathbf{9 , 7 6 5}$ & $\mathbf{1 5 , 0 5}$ & $\mathbf{6 , 7 0 2}$ & $\mathbf{9 , 8 7 5}$ & $\mathbf{8 , 8 3 4}$ & $\mathbf{6 , 6 8}$ & $\mathbf{8 , 1 2 4}$ & $\mathbf{5 , 5 1 0}$ \\
\hline
\end{tabular}

Sumber : Hasil pengolahan data, 2015

Tabel 2. Nilai Eigen Vector Relatif berpasangan ternormalisasi antara Kriteria Materi/ Informasi Penyuluhan Perikanan yang diprioritaskan di Wilayah Perkotaan pada Pengelolaan Usaha Budidaya Ikan

\begin{tabular}{cccccccccc}
\hline & $\mathrm{a}$ & $\mathrm{b}$ & $\mathrm{c}$ & $\mathrm{d}$ & $\mathrm{e}$ & $\mathrm{f}$ & $\mathrm{g}$ & $\mathrm{h}$ & $\sum$ \\
\hline $\mathrm{a}$ & 0,102 & 0,159 & 0,103 & 0,12 & 0,077 & 0,103 & 0,114 & 0,088 & $\mathbf{0 , 8 6 7}$ \\
$\mathrm{b}$ & 0,043 & 0,066 & 0,103 & 0,08 & 0,048 & 0,071 & 0,084 & 0,06 & $\mathbf{0 , 5 5 6}$ \\
$\mathrm{c}$ & 0,148 & 0,096 & 0,149 & 0,192 & 0,156 & 0,157 & 0,148 & 0,142 & $\mathbf{1 , 1 8 8}$ \\
$\mathrm{d}$ & 0,086 & 0,084 & 0,079 & 0,101 & 0,083 & 0,143 & 0,109 & 0,124 & $\mathbf{0 , 8 0 9}$ \\
$\mathrm{e}$ & 0,151 & 0,156 & 0,108 & 0,138 & 0,113 & 0,103 & 0,095 & 0,097 & $\mathbf{0 , 9 6 1}$ \\
$\mathrm{f}$ & 0,149 & 0,14 & 0,143 & 0,106 & 0,165 & 0,15 & 0,17 & 0,164 & $\mathbf{1 , 1 8 6}$ \\
g & 0,111 & 0,098 & 0,124 & 0,114 & 0,146 & 0,109 & 0,123 & 0,142 & $\mathbf{0 , 9 6 7}$ \\
h & 0,21 & 0,202 & 0,19 & 0,148 & 0,211 & 0,166 & 0,157 & 0,181 & $\mathbf{1 , 4 6 5}$ \\
\hline & & & & & & & Total & $\mathbf{8 , 0 0 0}$ \\
\hline
\end{tabular}

Sumber: Hasil pengolahan data, 2015 
Temuan penelitian ini diperoleh dengan melakukan berbagai perbandingan berpasangan antar kriteria, antar subkriteria dan antar alternatif yang ada untuk kepentingan pengambilan keputusan.

Hasil perbandingan berpasangan antara kriteria materi dan informasi penyuluhan perikanan yang diprioritaskan di wilayah perkotaan pada pengelolaan usaha budidaya ikan, dapat dilihat pada Tabel 1, Tabel 2, Tabel 3, dan Tabel 4. Konsistensi jawaban responden sangat diperlukan pada pengisian kuisioner yang didesain berdasarkan metode AHP. Consistency Ratio yang diperbolehkan hanya maksimal 10\%, hal ini diketahui setelah data dapat diolah. Pengumpulan pendapat antara satu faktor dengan yang lain adalah bebas satu sama lain, dan hal ini ternyata dapat mengarahkan kepada ketidakkonsistensi jawaban yang diberikan responden. Permasalahan yang terdapat didalam pengukuran pendapat manusia, konsistensi tidak dapat dipaksakan. Tolak ukur yang digunakan pada uji konsistensi adalah: Consistency Index berbanding Ratio Index atau Consistency Ratio. Nilai Consistency Ratio dari antara kriteria materi/informasi penyuluhan perikanan yang diprioritaskan di wilayah perkotaan pada pengelolaan usaha budidaya ikan, sebagaimana tercantum pada Tabel 3.

Tabel 3. Nilai Consistency Ratio antara Kriteria Materi/Informasi Penyuluhan Perikanan yang diprioritaskan di Wilayah Perkotaan pada Pengelolaan Usaha Budidaya Ikan

\begin{tabular}{clc}
\hline No. & \multicolumn{1}{c}{ Uraian } & Nilai \\
\hline 1. & Lambda & 8,137 \\
2. & Consistency Index $(\mathrm{CI})$ & 0,02 \\
3. & Ratio Index (RI) & 1,41 \\
4. & Consistency Ratio $(\mathrm{CR})$ & $1,4 \%$ \\
\hline
\end{tabular}

Sumber: Hasil pengolahan data, 2015

Tabel 4. Penetapan Prioritas pada Kriteria Materi/Informasi Penyuluhan Perikanan di Wilayah Perkotaan pada Pengelolaan Usaha Budidaya Ikan

\begin{tabular}{clcc}
\hline No. Kriteria & \multicolumn{1}{c}{ Uraian Kriteria } & Bobot (\%) & Ranking \\
\hline a & $\begin{array}{l}\text { Penumbuhan dan pengembangan peran dan } \\
\text { fungsi kelompok perikanan }\end{array}$ & 10,8 & 6 \\
b & $\begin{array}{l}\text { Penyusunan aturan pengelolaan keuangan } \\
\text { usaha perikanan }\end{array}$ & 6,9 & 8 \\
c & Penguasaan teknis budidaya perikanan & 14,8 & 3 \\
d & Pembangunan kemitraan strategis & 10,1 & 7 \\
e & Pembangunan jejaring pemasaran & 12,0 & 5 \\
f & Penyusunan perencanaan dan pengembangan & 14,8 & 2 \\
g & usaha & 12,2 & 4 \\
h & Penyusunan SOP budidaya perikanan & 18,4 & 1 \\
\hline
\end{tabular}

Sumber: Hasil pengolahan data, 2015 
Nilai CI pada Tabel 3 dihitung dengan rumus $C I=\left(\lambda_{\max }-n\right) /(n-1)$ dengan $n$ adalah jumlah kriteria (dalam hal ini 8), jadi CI $=(8,137-8) /(8-1)=0,137 / 7=0,02$. CI tidak sama dengan nol yang berarti pembobotan yang telah dilakukan tidak konsisten, semakin tinggi nilai $\mathrm{Cl}$ semakin tinggi pula tingkat ketidak konsistensian dari keputusan perbandingan yang telah dilakukan. Batas yang ditoleransi ketidak konsistenan dapat ditentukan oleh nilai random $\mathrm{CR}$ yang diperoleh dengan rumus $\mathrm{CR}=\mathrm{CI} / \mathrm{RI}$, jadi $\mathrm{CR}=0,02 / 1,41=1,4 \%$. Nilai CI sebesar 0,02 berarti pembobotan yang dibuat tidak terlalu konsisten, namun karena nilai $\mathrm{CR}=1,4 \%$ lebih kecil dari $10 \%$, maka ketidak konsistenan ini masih bisa diterima atau dipertanggungjawabkan.

Pembagian nilai jumlah baris pada eigen vector relatif berpasangan yang terdapat pada Tabel 2 dengan jumlah total dari nilai kolom yang bersangkutan, kemudian dikalikan $100 \%$ akan menghasilkan nilai bobot prioritas. Bobot untuk kriteria " $a "=(0,867 / 8) \times 100 \%=$ $10,8 \%$; bobot untuk kriteria " $b$ " = $(0,556 / 8) \times 100 \%=6,9 \%$; bobot untuk kriteria "c" $=(1,188 / 8) \times 100 \%=14,8 \%$; bobot untuk kriteria "d" $=(0,809 / 8) \mathrm{x}$ $100 \%=10,1 \%$; bobot untuk kriteria "e" = $(0,961 / 8) \times 100 \%=12 \%$; bobot untuk kriteria "f" $=(1,186 / 8)$ x $100 \%=14,8 \%$; bobot untuk kriteria " $\mathrm{g} "=(0,967 / 8) \mathrm{x}$ $100 \%=12,2 \%$; bobot untuk kriteria " $\mathrm{h} "=$
$(1,465 / 8) \times 100 \%=18,4 \%$. Prioritas hasil perhitungan kriteria-kriteria materi atau informasi dari penyuluhan perikanan di wilayah perkotaan pada pengelolaan usaha budidaya ikan kemudian dituangkan dalam matrik hasil yang ada pada Tabel 4 .

Data hasil olahan pada Tabel 4 menunjukkan kriteria penerapan budidaya perikanan yang ramah lingkungan dan pelestarian ekosistem merupakan kriteria dengan prioritas yang paling penting dalam penentuan materi dan informasi penyuluhan perikanan di suatu wilayah perkotaan di kegiatan pengelolaan usaha budidaya ikan, dengan bobot 18,4\%, kemudian tercatat kriteria penyusunan perencanaan serta pengembangan usaha dengan bobot $14,8 \%$ sebagai prioritas kedua, kriteria penguasaan teknis budidaya perikanan dengan bobot $14,8 \%$ sebagai prioritas yang ketiga. Prioritas keempat ditempati suatu kriteria penyusunan SOP budidaya perikanan (bobot 12,2\%), prioritas yang kelima ditempati kriteria pembangunan jejaring pemasaran (bobot $12 \%$ ), diikuti prioritas berikutnya kriteria penumbuhan dan pengembangan peran dan fungsi kelompok perikanan (bobot $10,8 \%$ ), kriteria pembangunan kemitraan strategis (bobot 10,1\%), dan prioritas terakhir ditempati oleh kriteria penyusunan aturan pengelolaan keuangan usaha perikanan (bobot 6,9\%). 
Penggunaan Analytical Hierarchy Process dalam Penentuan Prioritas Penyuluhan Perikanan di Wilayah Perkotaan pada Pengelolaan Usaha Budidaya Perikanan: Kasus di Kota Bogor

Tabel 5. Urutan Sub Kriteria Materi/Informasi Penyuluhan Perikanan di Wilayah Perkotaan pada Pengelolaan Usaha Budidaya Ikan sesuai Kebutuhan Pembudidaya Ikan sebagai Sasaran Penyuluhan

\begin{tabular}{lcccc}
\hline Sub kriteria materi/informasi penyuluhan & $\begin{array}{c}\text { Bobot } \\
\text { eigenvector } \\
\text { kriteria }\end{array}$ & $\begin{array}{c}\text { Bobot } \\
\text { eigenvector } \\
\text { sub kriteria }\end{array}$ & $\begin{array}{c}\text { (Bobot } \\
\text { kriteria) } \\
\text { X }\end{array}$ \\
$\begin{array}{l}\text { Bobot sub } \\
\text { kriteria) }\end{array}$ & Prioritas \\
\hline $\begin{array}{l}\text { Pengembangan usaha yang produktif dan } \\
\text { berkelanjutan }\end{array}$ & 0,142 & 0,428 & 0,061 & 1 \\
$\begin{array}{l}\text { Peran dan fungsi kelompok } \\
\text { Kegiatan budidaya ikan yang ramah }\end{array}$ & 0,111 & 0,512 & 0,057 & 2 \\
$\begin{array}{l}\text { lingkungan } \\
\text { Menghasilkan produk sesuai kebutuhan } \\
\text { pasar }\end{array}$ & 0,180 & 0,319 & 0,057 & 3 \\
$\begin{array}{l}\text { Pengelolaan kualitas air } \\
\text { Penyusunan pola tanam dan jadwal } \\
\text { produksi }\end{array}$ & 0,123 & 0,360 & 0,044 & 4 \\
$\begin{array}{l}\text { Kemitraan dengan pemasok bahan baku } \\
\text { atau sarana produksi }\end{array}$ & 0,095 & 0,406 & 0,039 & 5 \\
$\begin{array}{l}\text { Pencatatan dan pemeriksaan keuangan } \\
\text { Sumber: }\end{array}$ & 0,066 & 0,266 & 0,018 & 7 \\
\hline
\end{tabular}

Sumber: Hasil pengolahan data, 2015

Tabel 6. Overall composite weight pemilihan alternatif strategi penyuluhan perikanan yang efektif di wilayah perkotaan pada pengelolaan usaha budidaya ikan

\begin{tabular}{|c|c|c|c|c|c|}
\hline No. & $\begin{array}{l}\text { Kriteria Materi/Informasi } \\
\text { Penyuluhan }\end{array}$ & Bobot & $\begin{array}{c}\text { Alternatif } 1 \\
\text { "Pengetahuan" }\end{array}$ & $\begin{array}{l}\text { Alternatif } 2 \\
\text { "Keterampilan" }\end{array}$ & $\begin{array}{l}\text { Alternatif } 3 \\
\text { "Sikap" }\end{array}$ \\
\hline 1. & $\begin{array}{l}\text { Penumbuhan dan } \\
\text { pengembangan peran dan } \\
\text { fungsi kelompok perikanan }\end{array}$ & 0,111 & 0,185 & 0,178 & 0,201 \\
\hline 2. & $\begin{array}{l}\text { Penyusunan aturan } \\
\text { pengelolaan keuangan usaha } \\
\text { perikanan }\end{array}$ & 0,066 & 0,202 & 0,18 & 0,181 \\
\hline 3. & $\begin{array}{l}\text { Penguasaan teknis budidaya } \\
\text { perikanan }\end{array}$ & 0,141 & 0,187 & 0,252 & 0,139 \\
\hline 4. & $\begin{array}{l}\text { Pembangunan kemitraan } \\
\text { strategis }\end{array}$ & 0,095 & 0,193 & 0,179 & 0,191 \\
\hline 5. & $\begin{array}{l}\text { Pembangunan jejaring } \\
\text { pemasaran }\end{array}$ & 0,123 & 0,198 & 0,195 & 0,171 \\
\hline 6. & $\begin{array}{l}\text { Penyusunan perencanaan dan } \\
\text { pengembangan usaha }\end{array}$ & 0,142 & 0,197 & 0,217 & 0,154 \\
\hline 7. & $\begin{array}{l}\text { Penyusunan SOP budidaya } \\
\text { perikanan }\end{array}$ & 0,115 & 0,173 & 0,183 & 0,207 \\
\hline 8. & $\begin{array}{l}\text { Penerapan budidaya perikanan } \\
\text { yang ramah lingkungan dan } \\
\text { pelestarian ekosistem }\end{array}$ & 0,18 & 0,18 & 0,174 & 0,211 \\
\hline & Composite Weight & & $\mathbf{0 , 1 8 3}$ & 0,191 & $\mathbf{0 , 1 7 7}$ \\
\hline
\end{tabular}

Sumber: Hasil pengolahan data, 2015 
Prosedur yang sama telah dilakukan untuk: (a) melakukan ranking pada masing-masing kriteria untuk materi dan informasi penyuluhan tentang perikanan dengan sub kriterianya; serta (b) melakukan ranking alternatif-alternatif strategi penyuluhan perikanan untuk masing-masing kriteria materi/informasi penyuluhan perikanan. Prioritas sub kriteria materi atau informasi penyuluhan perikanan secara lengkap telah disajikan pada rincian Tabel 5, sedangkan perankingan alternatif strategi penyuluhan dapat dilihat pada Tabel 6.

\section{SIMPULAN}

Berdasarkan analisis yang telah dilakukan, maka dapat diambil kesimpulan sebagai berikut :

1. Dari delapan buah kriteria materiatau informasi penyuluhan perikanan yang dibutuhkan oleh pembudidaya ikan di wilayah perkotaan untuk mengatasi permasalahan umum yang dihadapi dalam usahanya, diprioritaskan tiga buah kriteria materi atau informasi penyuluhan secara berurutan, yakni :
a. Penerapan berbudidaya perikanan yang tetap ramah lingkungan dan pelestarian ekosistem;
b. Penyusunan suatu perencanaan serta pengembangan usaha; dan
c. Penguasaan tahap teknis budidaya perikanan.

2. Dari 30 (tiga puluh) buah sub kriteria materi atau/dan informasi penyuluhan perikanan yang selalu dibutuhkan oleh para pembudidaya ikan di wilayah perkotaan, yang dalam upaya untuk mengatasi permasalahan khusus (akar permasalahan) yang dihadapi dalam usahanya, diprioritaskan delapan buah sub kriteria materi atau informasi penyuluhan secara berurutan, yakni:

a. Pengembangan kegiatan usaha yang produktif dan berkelanjutan;

b. Peran dan fungsi kelembagaan;

c. Kegiatan berbudidaya ikan yang ramah lingkungan;

d. Menghasilkan berbagai variasi produk sesuai kebutuhan pasar;

e. Pengelolaan kualitas air;

f. Penyusunan tahap pola tanam dan jadwal produksi;

g. Kemitraan dengan ciri pemasok bahan baku atau sarana produksi;

h. Pencatatan serta juga melakukan pemeriksaan keuangan.

3. Alternatif "keterampilan" dipilih sebagai strategi penyuluhan perikanan yang paling efektif di wilayah perkotaan pada pengelolaan usaha budidaya ikan sesuai kebutuhan pembudidaya ikan sebagai sasaran penyuluhan, dengan skor 0,191, sedangkan pencapaian alternatif "pengetahuan" dengan skor 0,183 dan "sikap" dengan skor 0,177 hanya 
menjadi pilihan alternatif kedua dan ketiga.

\section{SARAN}

Berdasarkan hasil penelitian ini, terdapat beberapa hal yang dapat dilakukan untuk pengembangan lebih lanjut dalam penyelenggaraan penyuluhan perikanan di wilayah perkotaan pada pengelolaan usaha budidaya ikan, secara umum kepada seluruh pemangku kepentingan terkait dan khususnya kepada Kepala Dinas Pertanian Kota Bogor dan Kepala Kantor Ketahanan Pangan Kota Bogor, disarankan beberapa hal sebagai berikut:

1. Dalam rangka mengatasi berbagai permasalahan dan aspek-aspek terkini sedang dihadapi oleh pembudidaya ikan dalam usahanya di wilayah perkotaan, hendaknya disediakan media penyuluhan perikanan tercetak dan tertayang.

2. Mengusahakan tersedianya sumber daya manusia, sumber dana, sumber informasi dan sarana prasarana pendukung guna dapat tercapainhya penyelenggaraan penyuluhan sesuai prioritas yang terhadap sub-kriteria materi atau informasi penyuluhan perikanan yang dibutuhkan oleh pembudidaya ikan di wilayah perkotaan untuk berupaya mengatasi permasalahan pada khususnya (akar permasalahan) yang dihadapi dalam usahanya, berupa: (i) Pengembangan usaha yang tetap produktif dan berkelanjutan; (ii) Peran dan fungsi kelompok; (iii) Kegiatan budidaya ikan yang ramah lingkungan; (iv) Menghasilkan sesuatu produk sesuai kebutuhan pasar; (v) Pengelolaan kualitas air; (vi) Penyusunan pola tanam dan jadwal produksi; (vii) Kemitraan dengan pemasok bahan baku atau sarana produksi; dan (viii) Pencatatan serta kegiatan rutin pemeriksaan keuangan.

3. Mengutamakan pemilihan metode dan teknik penyuluhan perikanan yang dapat mendukung proses peningkatan perilaku pada ranah keterampilan sebagai alternatif strategi penyuluhan yang efektif.

\section{DAFTAR PUSTAKA}

Amanah S. (2008). Sistem penyuluhan perikanan dalam mengantisipasi era perubahan. Jurnal Penyuluhan, Vol. 4 (2): 140-151.

Amanah S, Fatchiya A, dan Syahidah D. (2004). Pemodelan suatu penyuluhan perikanan pada masyarakat pesisir melalui suatu pendekatan partisipatif. Bogor: Departemen SEI, FPIK Institut Pertanian Bogor.

Badan Pusat Statistik Provinsi Jawa Barat (2015). Jawa barat dalam angka tahun 2014. Bandung: Badan Pusat Statistik Provinsi Jawa Barat. 
Fatchiya A. (2010). Pola pengembangan kapasitas pembudidaya ikan kolam air tawar di Provinsi Jawa Barat. Bogor: Sekolah Pasca Sarjana, Institut Pertanian Bogor.

Hanan A, Sinaga WH, Nurmalia N dan Leilani A. (2013). Analisis tingkat adopsi inovasi teknologi budidaya ikan lele sangkuriang pada anggota kelompok ranca kembang di Kecamatan Cipanas Kabupaten Lebak Provinsi Banten. Jurnal Penyuluhan Perikanan dan Kelautan, ISSN 1978-6514, Vol.7 (1): 1-15.

Rijayana I, dan Okirindho L. (2012). Sistem pendukung keputusan pemilihan karyawan berprestasi berdasarkan kinerja menggunakan metode Analityc Hierarcy Process. Seminar Nasional Informatika (SEMNASIF) Vol 1 (5) Yogyakarta: Universitas Pembangunan Nasional "Veteran" Yogyakarta.

Rochmasari L, Suprapedi, dan Subagyo H. (2010). Penentuan prioritas usulan sertifikasi guru dengan metode Analytic Hierarchy Process AHP. Jurnal Teknologi Informasi, Vol 6 (1): 116-121.

Salampessy YLA. (2012). Efektivitas metode penyuluhan dalam peningkatan pemahaman SUT konservasi petani (kasus Kelurahan Gerem Kota Cilegon Provinsi Banten). Jurnal Ilmu Pertanian dan Perikanan, Vol 1 (1): 49-53. 